\title{
Pelatihan Penyusunan Modul Fisika Berbasis Asesmen Kompetensi Minimum Bagi Guru Fisika Madrasah Aliyah di Kabupaten Jember
}

\author{
${ }^{*}$ Supeno ${ }^{1}$, Indarwati ${ }^{2}$, Sutarto ${ }^{3}$ \\ 1,2,3 Universitas Jember, Jember, Indonesia
}

\begin{tabular}{|c|c|}
\hline (A) Check for updates ${ }_{\text {open }}$ access & DOI: https://doi.org/10.53621/jippmas.v1i1.2 \\
\hline Informasi Artikel & ABSTRAK \\
\hline $\begin{array}{l}\text { Riwayat Artikel: } \\
\text { Diterima: 29 Juni } 2021 \\
\text { Revisi Akhir: } 29 \text { Juni } 2021 \\
\text { Disetujui: } 30 \text { Juni } 2021 \\
\text { Terbit: } 30 \text { Juni } 2021\end{array}$ & \multirow{8}{*}{$\begin{array}{l}\text { Pembelajaran di sekolah harus dilaksanakan secara interaktif, inspiratif, } \\
\text { menyenangkan, menantang, dan memotivasi peserta didik untuk } \\
\text { berpartisipasi aktif dalam proses pembelajaran. Untuk itu, sebelum } \\
\text { melaksanakan pembelajaran, guru harus mendesain perencanaan } \\
\text { pembelajaran sebelum diimplementasikan di dalam kelas. Perencanaan } \\
\text { pembelajaran meliputi penyusunan rencana pelaksanaan pembelajaran dan } \\
\text { penyiapan media dan sumber belajar, perangkat penilaian pembelajaran, dan } \\
\text { skenario pembelajaran. Salah satu sistem pendukung pembelajaran yang } \\
\text { dapat didesain oleh guru sebelum pelaksanaan pembelajaran adalah bahan } \\
\text { ajar dalam bentuk modul. Modul pembelajaran merupakan bahan ajar yang } \\
\text { dikemas secara sistematis dan menarik sedemikian rupa sehingga dapat } \\
\text { digunakan untuk memfasilitasi siswa dalam belajar secara mandiri. Modul } \\
\text { pembelajaran dapat didesain dengan mengintegrasikan berbagai aktivitas } \\
\text { belajar dan alat penilaian yang berorientasi pada asesmen kompetensi } \\
\text { minimum. Guru mata pelajaran fisika dalam naungan MGMP Fisika MAN } 2 \\
\text { Jember memiliki masalah dalam hal melakukan kegiatan pengembangan } \\
\text { profesi utamanya penulisan modul fisika. Tim pengusul yang merupakan } \\
\text { para dosen di FKIP Universitas Jember merasa perlu untuk pengadaan } \\
\text { pelatihan penulisan modul fisika untuk para guru di sekolah tersebut. } \\
\text { Dengan kegiatan ini diharapkan dapat meningkatkan kemampuan guru } \\
\text { dalam menulis modul fisika yang berpotensi untuk digunakan untuk } \\
\text { mendukung proses pembelajaran fisika yang berkualitas sehingga mereka } \\
\text { mampu mengembangkan kompetensi profesionalisme guru. }\end{array}$} \\
\hline Kata Kunci: & \\
\hline Asesmen kompetensi minimum & \\
\hline Guru fisika & \\
\hline Madrasah Aliyah & \\
\hline Modul fisika & \\
\hline Pelatihan & \\
\hline 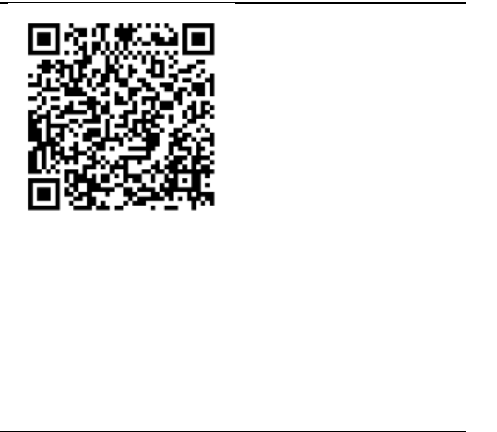 & \\
\hline
\end{tabular}

\section{PENDAHULUAN}

Pembelajaran di sekolah harus dilaksanakan secara interaktif, inspiratif, menyenangkan, menantang, dan memotivasi peserta didik untuk berpartisipasi aktif dalam proses pembelajaran. Pembelajaran yang dilakukan oleh guru harus memberi ruang yang cukup dalam mengembangkan prakarsa, kreativitas, dan kemandirian sesuai dengan bakat, minat, dan perkembangan fisik serta psikologis peserta didik (Ma'ruf, 2009; Chaerunnisa, Syauqiyah, \& Ekanara, 2017). Untuk itu, sebelum melaksanakan pembelajaran, guru harus mendesain perencanaan pembelajaran sebelum diimplementasikan di dalam kelas (Kilbane dan Milman, 2014; Yuniati \& Prayoga, 2019). Perencanaan pembelajaran meliputi penyusunan rencana pelaksanaan pembelajaran dan penyiapan media dan sumber belajar, lembar kerja peserta didik, perangkat penilaian pembelajaran, dan skenario pembelajaran.

Pelaksanaan pembelajaran di kelas harus diarahkan pada pengembangan tiga ranah kompetensi, yaitu sikap, pengetahuan, dan keterampilan (Anderson \& Krathwohl, 2001; Popham, 2017). Dalam pelaksanaan pembelajaran, ketiga ranah kompetensi tersebut memiliki proses psikologis yang berbeda (Permendikbud, 2016). Ranah sikap diperoleh melalui aktivitas menerima, menjalankan, menghargai, menghayati, dan mengamalkan. Ranah pengetahuan diperoleh melalui aktivitas mengingat, memahami, menerapkan, 
menganalisis, mengevaluasi, mencipta. Ranah keterampilan diperoleh melalui aktivitas mengamati, menanya, mencoba, menalar, menyaji, dan mencipta.

Penyiapan media dan bahan ajar juga menjadi bagian yang harus dilakukan oleh guru sebelum mereka melaksanakan pembelajaran di kelas (Smaldino et al., 2019; Supeno et al., 2018). Salah satu bentuk bahan ajar yang dapat digunakan oleh guru dan siswa dalam proses pembelajaran adalah modul pembelajaran. Modul merupakan bahan ajar cetak yang dirancang untuk dapat dipelajari secara mandiri dan memiliki struktur yang sistematis berisi materi pembelajaran, kegiatan belajar dan alat evaluasi untuk mencapai kompetensi yang diharapkan (Dharma, 2008). Modul pembelajaran harus dikemas secara sistematis dan menarik sedemikian rupa sehingga dapat digunakan untuk memfasilitasi siswa dalam belajar secara mandiri. Modul pembelajaran dapat didesain dengan mengintegrasikan berbagai aktivitas belajar dan bentuk penilaian. Dalam proses pembelajaran fisika, guru dapat mendesain modul yang mengintegrasikan proses inkuiri dalam mengkonstruksi pengetahuan (Astuti, Hartini, \& Mastuang, 2018; Prabowo, Ibrohim, \& Saptasari, 2016). Selain itu, beberapa teknik penilaian seperti penilaian project, penilaian produk, dan penilaian portofolio dapat diintegrasikan dalam modul pembelajaran.

Perencanaan terhadap penilaian proses dan hasil pembelajaran hal penting yang harus disiapkan oleh guru (Orlich et al., 2010). Permendikbud No. 65 Tahun 2016 tentang Standar Penilaian menyatakan bahwa penilaian pembelajaran dilaksanakan oleh guru dengan menggunakan pendekatan penilaian otentik yang menilai kesiapan peserta didik, proses, dan hasil belajar secara utuh. Keterpaduan penilaian ketiga komponen tersebut akan menggambarkan kapasitas, gaya, dan perolehan belajar peserta didik yang mampu menghasilkan dampak instruksional pada aspek pengetahuan dan dampak pengiring pada aspek sikap. Hasil penilaian otentik selanjutnya digunakan oleh guru untuk merencanakan program perbaikan pembelajaran, pengayaan, atau pelayanan konseling. Selain itu, hasil penilaian otentik digunakan oleh guru sebagai bahan untuk memperbaiki proses pembelajaran. Penilaian proses pembelajaran dilakukan saat proses pembelajaran dengan menggunakan berbagai alat penilaian, yaitu lembar pengamatan, angket sebaya, rekaman, catatan anekdot, dan refleksi. Penilaian hasil pembelajaran dilakukan saat proses pembelajaran dan di akhir satuan pelajaran dengan menggunakan berbagai metode dan alat penilaian.

Fakta yang terjadi di lingkungan sekolah saat ini, banyak guru yang kurang memiliki kemampuan untuk membuat modul pembelajaran yang mengintegrasikan berbagai aktivitas belajar dan berbagai teknik penilaian. Bagi guru, menulis modul pembelajaran menjadi hal yang berat mengingat beban mengajar 24 jam per minggu serta masih dibebani dengan berbagai tugas tambahan lainnya. Padahal modul pembelajaran merupakan bahan ajar yang sangat penting untuk mendukung terlaksananya proses pembelajaran yang berkualitas.

Berdasarkan uraian situasi di atas, para guru fisika dalam naungan MGMP MAN 2 Jember ternyata mengalami masalah dalam menulis modul pembelajaran fisika. Masalah tersebut disebabkan oleh kurangnya kemampuan guru untuk menulis modul. Oleh karenanya tim pengusul yang merupakan dosen Fakultas Keguruan dan Ilmu Pendidikan Universitas Jember berpikir untuk perlu diadakan pembinaan di tempat tersebut dalam upaya agar memotivasi guru untuk menulis modul pembelajaran fisika sehingga mereka mampu mengembangkan kompetensi profesionalisme guru dan meningkatkan kualitas pembelajarannya. 


\section{PERMASALAHAN}

Diperlukan adanya kegiatan pelatihan penyusunan modul fisika berbasis asesmen kompetensi minimum bagi guru fisika madrasah aliyah di kabupaten Jember. Tim pengusul dan mitra telah berdiskusi dan sepakat untuk membuat prioritas masalah yang akan diselesaikan sebagai berikut.

1. Bagaimana peningkatan kemampuan guru Madrasah Aliyah di kabupaten Jember dalam mendesain modul ajar untuk mendukung pembelajaran fisika?

2. Bagaimana peningkatan kemampuan guru Madrasah Aliyah di kabupaten Jember dalam mendesain asesmen kompetensi minimum untuk mendukung pembelajaran fisika?

\section{METODE PELAKSANAAN}

Kegiatan pengabdian masyarakat ini dilaksanakan di Madrasah Aliyah Negeri 2 Jember kabupaten Jember selama 7 bulan, yaitu bulan Februari 2020 hingga Agustus 2020. Lokasi Madrasah Aliyah Negeri 2 Jember berada cukup dekat dengan pusat kota, tepatnya beralamatkan di Jalan Manggar No. 72 Jember. Akses lokasi kegiatan dari Universitas Jember cukup mudah karena banyak alternatif jalan yang dapat dilalui menuju ke lokasi. Kegiatan ini berlangsung di Ruang Aula Madrasah Aliyah Negeri 2 Jember kabupaten Jember. Selama pelaksanaan pengabdian masyarakat, kegiatan pelatihan penyusunan modul fisika berbasis asesmen kompetensi minimum ada tiga materi yang diberikan meliputi:

1. Materi 1 : pendalaman materi fisika.

2. Materi 2 : asesmen kompetensi minimum dalam pembelajaran fisika.

3. Materi 3 : penyusunan modul fisika.

Sesuai dengan permasalahan yang ada, khalayak sasaran dalam kegiatan pengabdian kepada masyarakat ini adalah guru-guru mata pelajaran fisika yang tergabung dalam MGMP Fisika dalam naungan Madrasah Aliyah Negeri 2 Jember kabupaten Jember. Peserta pelatihan ini sebanyak 30 guru mata pelajaran fisika dari beberapa Madrasah Aliyah yang ada di kabupaten Jember.

Metode kegiatan yang diberikan dalam kegiatan pelatihan penyusunan modul fisika berbasis asesmen kompetensi minimum bagi guru fisika madrasah aliyah di kabupaten Jember berupa kegiatan pemberian materi, diskusi, dan praktik menulis modul fisika. Kegiatan pelatihan diawali penjelasan tentang konsep-konsep fisika yang bersifat fundamental. Selanjutnya, peserta pelatihan diberi penjelasan tentang asesmen kompetensi minimum dalam pembelajaran fisika. Kegiatan berikutnya adalah pemberian materi inti tentang penulisan modul fisika. Berikut ini adalah tahapantahapan pelatihan yang dilakukan.

1. Tahap Persiapan

Tahap persiapan meliputi survey dan penentuan, serta pemantapan lokasi dan sasaran.

2. Tahap Pelaksanaan

Pelaksanaan kegiatan pelatihan menggunakan beberapa bentuk metode pelatihan, yaitu:

a. Ceramah

Peserta dalam hal ini guru diberikan penjelasan mengenai materi fisika fundamental. Selanjutnya adalah kegiatan penjelasan mengenai asesmen 
kompetensi minimum dalam pembelajaran fisika. Pemberian informasi diakhiri dengan penjelasan tentang modul fisika dan cara mengembangkannya.

b. Tanya Jawab

Setelah menerima penjelasan, para guru dapat menggali pengetahuan sebanyakbanyaknya mengenai penulisan modul fisika berbasis asesmen kompetensi minimum dengan bertanya kepada narasumber/pemateri.

c. Praktik

Peserta diberikan kesempatan untuk mempraktekan materi-materi yang diperoleh. Tujuannya adalah agar peserta pelatihan (guru) benar-benar menguasai materi yang diterima, mengetahui kemampuan untuk menerapkan penulisan modul fisika berbasis asesmen kompetensi minimum secara teknis dan mampu mengidentifikasi kesulitan (jika masih ada) untuk dipecahkan selama menulis modul.

\section{PELAKSANAAN}

Kegiatan pelatihan penyusunan modul fisika berbasis asesmen kompetensi minimum bagi guru fisika madrasah aliyah di kabupaten Jember telah selesai dilaksanakan. Pelatihan dilaksanakan mulai bulan Februari 2020 dan berlanjut dengan kegiatan pendampingan bagi peserta hingga pertengahan Agustus 2020. Kegiatan pelatihan ini diikuti oleh 30 guru mata pelajaran fisika yang tergabung dalam MGMP di madrasah aliyah se kabupaten Jember. Peserta sangat antusias selama kegiatan pelatihan berlangsung. Pelatihan dilaksanakan dengan menerapkan metode ceramah, tanyajawab, dan praktik yang memberikan kesempatan kepada peserta untuk mempraktekan langsung materi yang diperoleh.

Pelatihan diawali dengan menjelaskan pengertian modul fisika. Selain itu dijelaskan pula mengenai komponen dan peran modul dalam pembelajaran fisika di kelas. Modul adalah sebuah buku yang ditulis dengan tujuan agar peserta didik dapat belajar secara mandiri tanpa atau dengan bimbingan guru. Modul merupakan alat atau sarana pembelajaran yang berisi materi, metode, batasan-batasan, dan cara mengevaluasi yang dirancang secara sistematis dan menarik untuk mencapai kompetensi yang diharapkan sesuai dengan tingkat kompleksitasnya (Dharma, 2008). Modul berisi paling tidak tentang:

1. petunjuk belajar (petunjuk siswa/guru),

2. kompetensi yang akan dicapai,

3. content atau isi materi,

4. informasi pendukung,

5. latihan-latihan,

6. petunjuk kerja, dapat berupa Lembar Kerja (LK),

7. evaluasi,

8. balikan terhadap hasil evaluasi.

\section{HASIL DAN DISKUSI}

Pembelajaran dengan modul juga memungkinkan siswa yang memiliki kecepatan tinggi dalam belajar akan lebih cepat menyelesaikan satu atau lebih kompetensi dasar dibandingkan dengan peserta didik lainnya. Selain itu, juga meningkatkan kemampuan peserta didik untuk belajar sendiri tanpa tergantung kepada kehadiran pendidik.

Selama pelatihan, para peserta diberi motivasi untuk mulai mencoba mengembangkan modul. Dalam sesi ini juga diberi contoh-contoh modul yang sudah 
ada serta bagaimana cara menggunakannya saat proses pembelajaran. Setelah materi tentang memotivasi guru agar mau menulis modul, materi selanjutnya adalah menjelaskan tentang sistematika modul dan cara mengembangkan untuk setiap bagian dari modul. Pertama, dijelaskan mengenai bagian awal dari modul, yaitu petunjuk penggunaan modul dan kompetensi yang harus dicapai oleh siswa. Selanjutnya dijelaskan bagaimana cara mengembangkan content atau isi materi, informasi pendukung, latihan-latihan, serta petunjuk kerja, dapat berupa Lembar Kerja (LK). Bagian akhir dari sesi ini digunakan untuk menjelaskan bagaimana cara mengembangkan evaluasi dan balikan terhadap evaluasi. Setelah semua materi disampaikan peserta diberi kesempatan untuk bertanya mengenai hal-hal yang belum mereka pahami. Terlihat pada kesempatan tersebut, peserta cukup aktif dengan cukup banyak peserta yang bertanya kepada pemateri.

Selesai dengan tanya-jawab, tahap selanjutnya adalah peserta melakukan praktik untuk mengembangkan modul. Kegiatan ini dilakukan dalam beberapa sesi hingga proses pengembangan modul selesai. Selama kegiatan praktik mengembangkan modul, para pemateri memberikan bimbingan secara online menggunakan beberapa media, diantaranya email, whatsapp, video call, dan lainnya. Seluruh materi yang diberikan, tersampaikan dengan baik dan peserta sangat antusias dalam menerima materi selama kegiatan berlangsung. Guru menghasilkan produk berupa modul fisika walaupun belum sempurna namun sudah cukup untuk mendukung proses pembelajaran fisika.

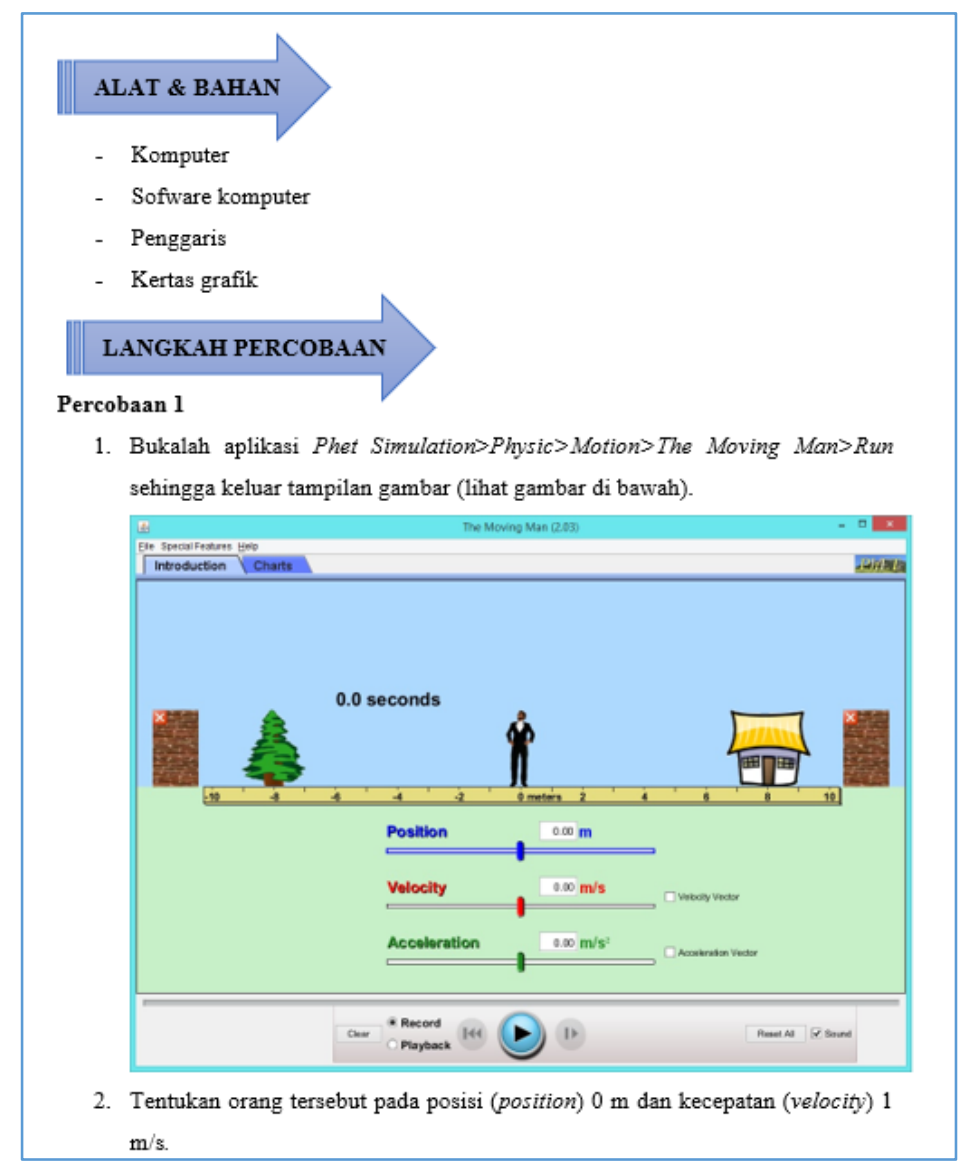

Gambar 1. Bagian dari modul yang memfasilitasi siswa belajar tentang posisi, kecepatan, dan percepatan benda. 


\section{EKSPLORASI KONSEP}

Lakukan analisa gambar diatas dengan menggunakan konsep vektor pada Kecepatan awal hingga kecepataan sesaat. Kemudian catatlah Besaran yang didapat pada Tabel 2.1. Untuk mengisi tabel 2.1, Perhatikan Langkah-langkah berikutt

1. Pahami grafik di atas dan kemudian analisa masing-masing titik.

2. Bagilah menjadi potongan gambar tiap titik berikut vector yang terdapat pada masing-masing titik. Langkah ini bisa digunakan untuk mengisi kolom ke 2 .

3. Analisa komponen vektor pada masing-masing titik, yang terdiri dari komponen pada sumbu $\mathrm{x}$ dan sumbu $\mathrm{y}$. Langkah ini bisa digunakan untuk mengisi kolom ke 3 dan ke 4 .

4. Untuk mendapatkan rumus kecepatan sesaat, ingat gerak yang bekerja pada arah sumbu x (horizontal) dan sumbu y (vertikal)

5. Carilah Besaran untuk posisi sesaat yang di dapat dari rumus kecepatan sesaat, seperti yang kita tahu bahwa hubungan antara posisi dengan kecepatan adalah $s=\frac{d v}{d t}$ atau $\frac{\Delta v}{\Delta t}$.

Gambar 2. Bagian dari modul yang memfasilitasi siswa belajar tentang posisi dan kecepatan saat mengalami gerak parabola.

Beberapa bagian dari tampilan modul yang dikembangkan oleh peserta ditunjukkan pada Gambar 1 dan Gambar 2 berikut ini. Ilustrasi pada Gambar 1 merupakan segmen dari modul yang dikembangkan pada materi fisika tentang kinematika. Dengan segmen tersebut, diharapkan siswa beraktivitas mengalami proses sains dalam rangka mengkonstruksi pengetahuan tentang posisi benda, kecepatan benda, dan percepatan benda. Ilustrasi pada Gambar 2 merupakan segmen dari modul yang dikembangkan pada materi fisika tentang gerak parabola. Dengan segmen tersebut, diharapkan siswa beraktivitas mengalami proses sains dalam rangka mengkonstruksi pengetahuan tentang posisi benda dan kecepatan benda saat mengalami gerak parabola.

\section{KESIMPULAN}

Guru fisika yang tergabung dalam MGMP Fisika Madrasah Aliyah se Kabupaten Jember yang mengikuti pelatihan kemampuannya dalam mendesain modul ajar untuk mendukung pembelajaran fisika. Guru fisika yang tergabung dalam MGMP Fisika Madrasah Aliyah se Kabupaten Jember yang mengikuti pelatihan bertambah kemampuannya dalam mendesain asesmen kompetensi minimum untuk mendukung pembelajaran fisika. Berdasarkan hasil kegiatan pelatihan yang dilakukan maka terdapat saran (1) Perlu tindak lanjut berupa pendampingan kepada guru dalam hal mengimplementasikan modul yang sudah dikembangkan dalam proses pembelajaran online, (2) Perlu tindak lanjut berupa pendampingan kepada guru dalam hal mengembangkan asesmen berbasis project untuk mendukung proses pembelajaran online, (3) Perlu tindak lanjut berupa kegiatan latihan untuk mengembangkan modul fisika untuk materi lainnya.

\section{UCAPAN TERIMA KASIH}

Ucapan terima kasih kami sampaikan kepada Universitas Jember yang telah mendanai PKM ini. 


\section{DAFTAR PUSTAKA}

Anderson, L. dan D. A. Krathwohl. 2001. Taxonomy for Learning, Teaching and Assessing: A Revision of Bloom's Taxonomy of Educational Objectives. New York: Longman.

Astuti, M., W., Hartini, S., \& Mastuang, M. 2018. Pengembangan modul IPA dengan menggunakan model pembelajaran inkuiri terbimbing pada materi suhu dan kalor untuk melatihkan keterampilan proses sains. Berkala Ilmiah Pendidikan Fisika, 6(2), 205-218.

Chaerunnisa, V., Syauqiyah, S. G., Ekanara, B. 2017. Pengembangan perangkat pembelajaran Biologi berorientasi pengembangan kecerdasan majemuk siswa pada konsep sel kelas XI SMA. Biodidaktika, 12(1), 30-37.

Dharma, S. 2008. Penulisan Modul. Jakarta: Direktorat Tenaga Kependidikan Direktorat Jenderal Peningkatan Mutu Pendidik Dan Tenaga Kependidikan Departemen Pendidikan Nasional.

Kilbane, C. R. dan N. B. Milman. 2014. Teaching Models: Designing Instruction for 21st Century Learners. New Jersey: Pearson.

Ma'ruf, Z. 2009. Implementasi pembelajaran aktif kreatif efektif dan menyenangkan (pakem) untuk pendidikan sains di sekolah. Jurnal Geliga Sains, 3(2), 19-28.

Orlich, D. C., R. J. Harder., R. C. Callahan, M. S. Trevisan, dan A. H. Brown. 2010. Teaching Strategies: A Guide to Effective Instruction, Ninth Edition. Boston: Wadsworth.

Permendikbud No. 22 Tahun 2016 tentang Standar Proses dalam Pendidikan Dasar dan Menengah.

Popham, W. J. 2017. Classroom Assessment: What Teachers Need to Know. Boston: Pearson.

Prabowo, C. A., Ibrohim, I., Saptasari, M. 2016. Pengembangan modul pembelajaran inkuiri berbasis laboratorium virtual. Jurnal Pendidikan: Teori, Penelitian, $\mathcal{E}$ Pengembangan, 1(6), 1090-1097.

Smaldino, S. E., D. L. Lowther, C. Mims. 2019. Instructional Technology and Media for Learning; 12th Edition. New Jersey: Pearson.

Supeno, S., Bektiarso, S., \& Munawaroh, A. 2018. Pengembangan pocketbook berbasis android untuk meningkatkan keterampilan berpikir kritis siswa SMA. Prosiding Seminar Nasional Fisika (SNF), 2, 76-83.

Yuniati, S \& Prayoga, S. 2019. Pengaruh manajemen perencanaan pembelajaran terhadap kinerja guru SMA Negeri di kota Mataram. Jurnal Kependidikan, 5(2), 133-140.

\footnotetext{
* Dr. Supeno, M.Si (Corresponding Author)

Universitas Jember,

J1. Kalimantan Tegalboto No.37, Kabupaten Jember, Jawa Timur 68121, Indonesia

Email: supeno.fkip@unej.ac.id
}

Prof. Dr. Indrawati, M.Pd.

Universitas Jember,

Jl. Kalimantan Tegalboto No.37, Kabupaten Jember, Jawa Timur 68121, Indonesia

Email: supeno.fkip@unej.ac.id

\section{Prof. Dr. Sutarto, M.Pd.}

Universitas Jember,

Jl. Kalimantan Tegalboto No.37, Kabupaten Jember, Jawa Timur 68121, Indonesia

Email: supeno.fkip@unej.ac.id 